\title{
Recognition and Public Policies: Analyzing the Relations between Scavengers and Public Power in Belo Horizonte, Brazil
}

\author{
Maria Cecília Gomes Pereira ${ }^{1} \&$ Marco Antonio Carvalho Teixeira ${ }^{1}$ \\ ${ }^{1}$ Graduate Program in Public Administration and Government, Getulio Vargas Foundation (FGV-EAESP), São \\ Paulo, Brazil \\ Correspondence: Maria Cecília Gomes Pereira, Fundação Getúlio Vargas (FGV-EAESP), Avenida 9 de Julho, \\ 2.029, 11 andar, Bela Vista, 01313-902, São Paulo-SP, Brazil. Tel: 55-1-197-960-6697. E-mail: \\ cecilia.pereira@fgv.br
}

Received: March 10, 2012 Accepted: March 29, 2012 Online Published: October 18, 2012

doi:10.5539/par.v1n1p61 URL: http://dx.doi.org/10.5539/par.v1n1p61

The research was supported by Coordination for the Improvement of Higher Education Personnel (CAPES).

\begin{abstract}
This article debates the dynamics of the scavengers' struggle in Belo Horizonte and its consequences reverted in specific public policies for this social group. We start from the idea of social struggle and conflict, going through the debates related to the struggle for recognition, by Axel Honneth. As a research method, we have adopted the case study analysing the period from 1987 to 2010. Deep interviews and spontaneous talks were conducted. For the analysis, the methodology of reading narratives was used. In the narratives, different forms of disrespect regarding scavengers and their claims to local governments were found, resulting in the construction of a specific public policy to support their work. Along the years, the policy has been modified and has recently been inflected, increasing the conflicts between the public power and the scavengers, denoting the challenges of the relation between government and civil society in the conduction of the public policy.
\end{abstract}

Keywords: scavengers, struggle for recognition, public policies

\section{Introduction}

Scavengers of recyclable waste are present almost everywhere in Brazil, working on the streets, landfills or dumpsites (Note 1), in their constant struggle for survival within the country's great social inequality. They are part of a dynamics in which they act like "outsourced workers" exploited by the recycling industry because they survive from the waste collected, with no rights that characterise the exercise of citizenship (Layargues, 2002; Bosi, 2008). At the same time, they are connected to a great urban environmental problem - the final disposal of waste.

From the final 80 's, scavengers have begun to organise themselves into associations and cooperatives. This process has initially taken place in some Brazilian cities such as São Paulo, Porto Alegre and Belo Horizonte, and represented a quest for truly satisfying their basic rights, among which the right to food, work, housing, health and others. This process has spread along the country in distinct forms, mostly from the 90's, reaching a national articulation in 2001 by the creation of the National Movement of Scavengers of Recyclable Waste (MNCR).

This article focuses on this dynamics of organisation into associations and cooperatives, debating the struggle of scavengers and its contribution to public policies, making use of Axel Honneth's $(2003 ; 2007)$ debates, which are part of the critical theory approach. For the author, the basis for interaction is the social conflict and its moral grammar, the struggle for recognition into a dialectic process of disrespect and recognition. Such approach offers elements that allow the discussion of the less visible aspects of social reality that are seen as natural, with special attention to human pain and suffering that are not always demonstrated. The perspective of the struggle for recognition is not restricted to the construction of governmental policies, it involves other dimensions in which the society is transformed and changes patterns of social relations through reflection. In the studied case, the analysis around the relation with the State is fundamental, once it has an important role in the processes of recognition, mainly in getting access to rights policies. This way, we debate whether and in what extent public policies incorporate social recognition issues. Public policies even if not leading, alone, to the social recognition of social groups in poverty, have a key role in the reduction of social inequality. 
In this article we analyse Asmare, an association of scavengers created in 1990 in Belo Horizonte (MG), and its relation with the local government. The main goal is the analysis of the Asmare scavengers' struggle and its contribution to public policies. We debate such struggle based on the notions and meanings taken from the narrative of the actors involved in the process. In the next section, we will introduce methodological procedures. Then, we will approach the theoretical debate of struggle for recognition by Axel Honneth and just then present the discussion of results reached in this research. Finally, we will present the final considerations.

\section{Research Methods}

The research has, as main methodological assumption, the perspective of theme field (Spink, 2003). Theme-field is a group of networks of inter-connected notions, a negotiated and built space in which arguments with distinct faces and materialities are in constant debate, in many places (Spink, 2003). Aiming to give voice, knowledge and arguments that are in constant notion negotiation within the chosen theme-field, we make use of two methods: the case study and narratives reading.

The case study method seeks to interpret contemporaneous phenomena inside their social context (Yin, 2001), analysing senses attributed to their experiences and social practices by the subjects (Godoy, 2006). The case study and narratives reading allows the understanding of the comings and goings of the scavengers' struggle and the constant tension between disrespect and recognition that constitutes social conflicts (Honneth, 2003). The time frame analysed was 1987 to 2010, since the process of organisation for Asmare scavengers began that year. The analysis of this period allowed us to explore the context and process of change over time, enabling a timely inter-connectivity between historical and actual phenomena (Pettigrew, 1990).

Aiming to rescue and analyse the events involved in the struggle of scavengers, debating the given notions, the network of meaning and arguments that inter-connect past and present (Spink, 2003), we adopted the narratives study, following the proposal elaborated by Czarniawska $(2000 ; 2004)$. The narrative study is the study over which actors tell their stories. The author highlights the fact that in all societies narratives bring knowledge, constituting the most typical form of social living and a common form of communication (Czarniawska, 2000; 2004).

The narrative, when telling past experiences, involves the creation of meaning in a retrospective process, in which there is a constant recreation and negotiation of meanings (Czarniawska, 2000; 2004). This way, the narrative could be understood as "the discourse that addresses actions that took place in the past" (Alves \& Blikstein, 2006).

Czarniawska (2000) proposes the use of narratives in researches based on the following dynamics: to observe how stories are created, to collect stories and provoke the act of telling stories to, later on, interpret them (what do they tell us?) and deconstruct stories, aiming to build your own story, as a researcher, opposing it to the other ones.

As a procedure for the collection of narratives, five open interviews were initially conducted in July 2010, as the research's exploratory stage, with four scavengers and one member of an organisation supporting Asmare, which were interviewed again in the research's next stage. Later on, in October, 18 semi-structured interviews were deeply conducted with seven Asmare's scavengers, four members of organisations that support the association, six today's and ex-members of the local government and one scavenger from another association.

From the exploratory phase and the initial interviews, we were able to map the actors involved in the experience. As the interviewees told their stories, they mentioned the names of people and organisations that had participated in the scavengers' organizational efforts. Thus, we interviewed the people most mentioned in the narratives. We conducted the interviews with the assistance of two questionnaires: one prepared for Asmare scavengers and another for members of support organisations and former and current members of Belo Horizonte's municipal government. We recorded and transcribed the interviews, by means of selecting the main speeches on each topic addressed in the questionnaires, and then analysed them according to Czarniawska's $(2000 ; 2004)$ narrative reading proposal.

In addition, we held several spontaneous conversations in different places and occasions. Based on these talks, we have identified notions, fragments and some parts of the stories not yet known. The availability for dialogue and the opening for daily conversations by the researcher, as highlighted by Spink (2008) are important elements to the collective construction of meanings. We noted the conversations in the field research notebook and analysed them using narrative reading so as to complement the interviews.

\section{The Struggle for Recognition and Social Conflicts: Axel Honneth's Approach}

The social recognition theme has been highlighted in the latest two decades not only in the academic scope, but also in public debates, social movements and in the countries' political agendas (Honneth, 1996; 2007; Mattos, 2006; Fraser \& Honneth, 2003; Mendonça, 2009). 
The notion of social recognition has its origins in Hegel's first work pieces (Honneth, 1996; 2007). Honneth (1996; 2003 ; 2007) points out that, no classical thinker but Hegel has focused on the principle of recognition. However, the concept has recently gained great importance with the emergence of public debate and social movements that have demanded a more accurate consideration of the idea of recognition. In this process, the multi-culturalism and feminist struggles' debates that share the idea that all individuals and social groups should be accepted and respected in their differences are included. In the latest decades, a plurality of uses of the recognition concept leading to a variety of meanings given to the main category is observed, as well as the problem of each semantic meaning being related to a specific moral perspective (Honneth, 1996; 2007).

In the contemporaneous debate, the main authors addressing the recognition theory are the Canadian political philosopher Charles Taylor, the North-American political scientist Nancy Fraser and the German philosopher and sociologist Axel Honneth. The three authors have distinct focuses and bases. Charles Taylor focuses on the historical-philosophic grounding of the social recognition thesis, even if, based on Hegel, the author originally reconstructs this category. Nancy Fraser (2007) bases her analysis on the recent social movements and political struggles that characterises them, bringing up a discussion of dualistic perspective between redistribution and knowledge, generating debates and dialogues with Axel Honneth in the discussion of recognition versus redistribution (Fraser \& Honneth, 2003). Axel Honneth lies within the scope of Society's Critical Theory (Note 2), and conflict is in the centre of his approach (Honneth, 1996, 2003, 2007, 2008a, 2008b, 2008c).

Axel Honneth (2003) based his theory on the Hegelian conceptual model of "struggle for recognition". For Hegel, the formation of the human identity presupposes the inter-subjective recognition's experience. Through reciprocal recognition, subjects establish a self-recognition with other subjects. But the quest for recognition is permeated by a struggle, in a way that social conflict leads to an increase in the relations of mutual recognition. Honneth (2003) also makes use of George Herbert Mead's social psychology to bring an empirical inflection to the Hegelian theory. Based on these main theoretical sources, Honneth seeks to ground the three forms of reciprocal recognition, the respective forms of practical self-relation given to the human being and the dynamics of disrespect.

The emotional dedication (love) is the first stage for the reciprocal recognition, being restricted to primary relations, that is to say, to the strong emotional connections between a few people such as the relation between two partners, friends and parents and their children. In the reciprocal loving relationship, subjects know they are united by the fact they are co-dependent in their state of needs and feelings of the other, in a precarious balance between autonomy and connection (Honneth, 2003).

The inter-subjective experience of love involves a continuous affective dedication, leading individuals to mutually reach an elementary trust on them. The practical self-relation generated is self-trust, that is to say, an existential confidence and a self-trust. This form of recognition is the psychic presupposition and the structural ground of the inter-subjective development of individuals. According to Hegel, self-trust is the indispensable basis for the autonomous participation in the public sphere (Honneth, 2003).

The second form of recognition happens through rights - juridical rights - and takes place when one can achieve a comprehension of self as a rights-bearer, when it achieves, on the opposite, the knowledge about duties one has to deliver to the other. Juridical recognition takes place through the respect to the attributes that make the individual a morally imputable person. Such attributes are grounded on universalist moral principles and on a cognitive understanding that undergo through processes of historical evolution. In these processes, not only the extension of rights to social groups that have been, so far, excluded from the status of being a rights-bearer, is present but also the extension of content (Honneth, 2003). Likewise, the existing tensions between proclaimed rights and effectively exercised rights are present (Marshall, 1967). The positive self-relation generated by the juridical recognition is self-respect. When considering one as a morally imputable person, the individual obtains the chance of conceiving its actions as a manifestation of its own autonomy that is respected by all the others.

The third form of reciprocal recognition refers to solidarity that takes place through social esteem. Social esteem has to do with the respect to private properties that characterises human beings on their differences, that is to say, it is a socially defined value of individuals' differential properties that contribute to the implementation of culturally defined goals. This value's definition presupposes a group of values which is inter-subjectively universally shared, that is created from a framework of orientations that is symbolically articulated. This frame is always open and porous and it is the place where ethical goals and values that constitute the cultural self-comprehension of a society are formed (Honneth, 2003).

The social esteem, as well as the juridical recognition, goes through historical and cultural variations and is defined, in essence, by the interpretations - that are historically dominant - of symbolically constructed social goals. The content of such interpretations is influenced by social groups that are able to publically interpret their own 
realisations and forms of living as valuable ones. The positive self-relation developed by the subject from this form of recognition is the self-esteem. This self-relation occurs when the individual is esteemed by its specific qualities both in the presentation of achievements or in the possession of capabilities that are recognised as valuable ones by other society members in a process of solidary acceptance (Honneth, 2003).

Honneth (2003) links to the three forms of recognition forms of disrespect and denied recognition. He highlights that non-recognition and the experience of disrespect can lead to psychic injuries capable of collapsing one's identity once it can harm the positive self-comprehension of one's self.

Physical injuries include a type of disrespect that deeply hurts self-confidence developed through emotive dedication. The individual who suffers physical humiliation sees itself as deprived of the bodily manifestation of its autonomy, as a result, losing confidence on itself and on the world, expanding it to the practical relation with other subjects. The physical disrespect is not included in a process of historical change such as the two other types of disrespect.

The second form of disrespect refers to the deprivation of rights and the social exclusion that affect one's moral self-respect. They are situations in which human beings suffer on its dignity when they are structurally excluded from the possession of certain rights in a society. This way, moral accountability is not given to individuals in the same extent it is to other society members. This form of disrespect creates not only a limitation of a personal autonomy, but also a feeling of not possessing the status of an interaction partner of same value. The individual is affected on the inter-subjective expectation of being recognised as a capable subject, leading to a loss of self-respect (Honneth, 2003). This form of disrespect is historically variable, since the semantic content of what is considered to be a morally imputable person changes with the development of juridical relations. The deprivation of rights is related to the degree of universalisation, as well as to the material extension of rights. Therefore, it is related to the meaning of citizenship itself, that is, a historical concept, in which the meaning can vary according to time and space (Pinsky \& Pinsky, 2003).

The third form of disrespect regards degradation and offence when a depreciation of individual or collective lifestyles takes place, affecting self-esteem. When some forms of life are degraded or considered as if they were of lesser value, the chance of attributing a social value to these individuals is taken away. The devaluation of specific forms of self-realisation generates, in the individual, the lack of chance to understand him or herself as an esteemed being on its specific capabilities and particularities, that is to say, it leads to a loss of self-esteem (Honneth, 2003).

Sennett (2004) highlights that in modern societies the respect and recognition of people is something scarce. In many societies where the level of inequality is high, such as the Brazilian one, the great majority of people is daily disrespected through symbolic violence mechanisms (Souza, 2009).

Honneth (2003) argues that the experience of disrespect could become the motivational impulse for the struggle for recognition, once the affective tension from the injury of humiliation could be dissipated in the chance of active action. Such feelings could become the motivational ground for collective resistance when the subject is capable of articulating them in an inter-subjective frame of interpretation that proves them as they are experienced by a whole group. In this perspective, the emergence of social movements depends on a collective semantics that allows the interpretation of experiences of personal disrespect as something that affects not only an individual, but many others. According to the author, all social confrontations and all forms of conflict would be initially formed according to the same model of a struggle for recognition: in this case, every collective action of resistance and rebellion would be attributed, according to its origin, to an invariable framework of moral experiences, in which social reality is interpreted in compliance with a historically changing grammar of recognition and disrespect (Honneth, 2003, p.260)

The struggle for recognition is an unfinished and dialogic process, marked by the dynamics of disrespect and recognition, dialectically. Honneth's approach has been the subject of criticism over the years, which led him to accomplish new developments in later works (Honneth, 2008a; 2008b; 2008c). The main objections involved the debate surrounding the concepts of recognition and redistribution, especially between the author and Nancy Fraser. Fraser (2007) argues that Honneth subsumed the struggles for distribution into recognition and assumes a culturalist reductionist perspective of distribution, presuming economic inequalities are rooted in cultural elements. She proposes a dualist perspective based on an ample concept of justice that encompasses both redistribution and recognition, involving the notion of participation parity (Fraser, 2007). In opposition to Fraser, Honneth (2007, p.92) highlights that "conflicts over distribution, provided they are not merely concerned with applying institutionalised rules, are always symbolic struggles to legitimise the sociocultural device that establishes the value of activities, attributes and contributions". For Honneth (2007), recognition encompasses the dimension of distribution demands, so that struggles for recognition are present in all redistribution conflicts. 


\section{The Struggle of Asmare's Scavengers Based on the Reading of Narratives}

4.1 In the Middle of Waste and Mistaken for Waste: the Beginning of A New Perception of Things through the Arrival of the Pastoral de Rua (Street Pastoral) (1987-1992)

The organisation process of Asmare's scavengers has begun in 1987, when sisters of the Fraternidade das Oblatas de São Bento arrived to Belo Horizonte and created the Catholic Church's Street Pastoral aiming to offer support to the homeless.

Initially, Pastoral members mapped places where homeless were largely concentrated and realised how expressive was the number of people living out of recyclable waste - scavengers is how they called each other. At that time, scavengers were literally mistaken for waste. One of the Benedictine sisters reported that "society did not believe and no one recognised them as persons" (free translation). They were not considered citizens and therefore respected and esteemed by society, they suffered different forms of disrespect.

Scavengers suffered several violent actions such as physical aggression. The Department of Urban Cleaning (SLU, in Portuguese) performed what they called "cleaning operation", forcibly expelling them using the police support at the places where they worked and taking the material collected by them to the landfill. Scavengers reported different forms of physical aggression suffered by them. In such conditions, marked by physical abuse, scavengers' self-confidence was extremely shaken. Another form of disrespect present in the narratives regards the deprivation of rights, such as the denial of the right to work, to be fed, to health, education and housing, among other rights that represent the right of citizenship. The total deprivation of rights marked the situation of this group. A scavenger has mentioned that,

I didn't think I was a citizen, I was, but I didn't think I was, [...] I thought I didn't have the same rights everyone had, I thought my rights were lesser than everyone else's. [...] Later I learnt I have the same rights that you do, anyone does. (Scavenger 1 -free translation)

Scavengers, besides not being considered as morally accountable individuals, equal in the interaction with others, faced another form of disrespect outlined by Honneth (2003) - degradation and offence. In many stories and situations, all scavengers reported suffering discrimination and prejudice. They were seen by the population as criminals and homeless and not like workers, as reported by a scavenger: "before, scavengers were seen as criminals, they were not seen as workers, but as if they were dirtying the city. We have suffered a lot of prejudice in the streets" (Scavenger 1 - free translation). Based on this report, it is possible to identify the disrespect and how the self-esteem was affected since their activities were not recognised as work.

It is interesting to notice that the three domains of recognition, and the corresponding disrespects, stated by Honneth (2003) are, in practice, very intertwined. The first sphere of recognition, the emotional dedication, with the corresponding form of disrespect, abuse and violation, in practice, is very intertwined to the other two spheres. When a scavenger was the target of a "cleaning operation", for instance, not only his civil rights were violated, but also his physical integrity, once they were usually physically aggressed in these occasions. And at the same time, they were offended and degraded since the activity they performed was not considered as work, but as a form of public nuisance and disturbance of the urban cleaning.

The Street Pastoral had to face this social context in order to start their work with scavengers. A coordinator and a former Pastoral member reported that they would approach them to talk and listen to them in small meetings, seeking to establish bonds of mutual trust. The interaction between the Pastoral team and the scavengers aimed to recognise the later into a socialisation process based on Christian values. This form of interaction seemed to be the key and the basis for the whole organisation dynamics that would follow the following years.

In1988, a "cleaning operation" took place and was reported by scavengers, by the coordinator and former Pastoral members as the turning point for the process of Asmare's construction. This event was informed through an open letter from the scavengers to the population of Belo Horizonte. An excerpt of the document is reported below:

The municipal government turned us into waste; we, scavengers, have families and children to take care of, we live today out of the collected paper. If it wasn't for us, the municipal government wouldn't be able to clean the city. The municipal government's inspectors arrived on August 22nd, at 4 a.m. throwing our sheds away with everything inside, including us. We had no time to collect our stuff. We lost everything we had: documents, belongings, we lost the paper. The sheds were placed in Contorno Avenue, next to Arrudas River, behind the bus station and we stood there, without anything and we had nowhere to go. Why does the municipal government injure us, scavengers? You have a family, and are human beings just like us. Would you like to live the same life we do, living under the bridges, marquees and running away from the Police? You depend on people like us the same way we depend on the waste to live. What can you do to help us? (our bold) 
In this stretch, it is interesting to specifically analyse the three last phrases once they denote the relation between the Brazilian State and the population in the same extent of the relation between the scavengers and the waste, both in a situation of dependence. The Brazilian State is for all and presupposes the existence of the population, as well as the process of universalisation of rights and duties. The scavenger, however, depends on the waste to survive since basic rights have been denied. These phrases express in a simple and deep way that "there are no rights if they are not for everyone", once the State is universal. Nevertheless, the reported situation shows the opposite.

In 1989, the action held by the Pastoral along with scavengers was intensified aiming to encourage the creation of an association. Scavengers reported that several meetings took place in different spaces such as bridges, streets, unoccupied lands and religious spaces. This process has culminated in the formation of Asmare, initially with 10 members, in a assemble that took place in April $27^{\text {th }} 1990$.

Asmare's first years were full of claims. Scavengers reported that several marches were organised and demonstrations were held in front of the city hall. Everyone that was interviewed narrated that. At the time, the relation with the municipal government was full of conflicts. The Street Pastoral sought to establish dialogues with the municipal government, but did not achieve satisfactory results. In the municipal chamber, they have obtained the support of a few city councillors.

The mobilisations and articulations have led, already in Asmare's first year, to an important achievement: the inclusion, in the Municipal Organic Law, of the statement that selective collection should be preferably made by cooperatives (Belo Horizonte, 1990). Another claim made to the public power was the construction of a shed for the selection and storage of the collected recyclable material. Once again several marches, demonstrations and negotiations occurred until the construction, in 1992, of a shed with minimal infra-structure in a land occupied by the scavengers.

This period's claims were related to the exercise of rights such as the right to work, to food, housing and to come and go, among others, and to the changes in the day to day interactions between scavengers and the population, in a struggle to be considered as individuals who are equal in their interaction with others. At the same time, a struggle against degradation and offence was intertwined, as well as against physical integrity violation.

The Benedictine sisters were the first ones to see the dimension of suffering experienced by the scavengers and to reflect about the relation between society and public power and this social group. In this period, the meanings attributed to the scavengers and to the work they conducted were associated to begging, delinquency, dirtiness and disturbance of urban cleaning both by the local government and the population.

Seeking to oppose these meanings, The Street Pastoral gave new ones to the scavengers and their work, highlighting the value of human life, the poverty situation, the exploitation and the violence to which they were submitted; considering them as workers whose job contributed to society, to urban cleaning and to environment conservation.

It is important to highlight that these meanings built at that time were part of a larger context. The end of the $80 \mathrm{~s}$ was marked by the country's redemocratisation, by the writing of the 1988 Federal Constitution, in a period of significant changes in the social and political scenario. In the beginning of the $90 \mathrm{~s}$, the environmental issue drew public attention, mainly through the Rio 92 Conference, in Brazil. After this conference, recycling has begun to disseminate in the country (Portilho, 2005). According to Honneth (2003), the political and cultural surroundings are fundamental so that experiences of disrespect become the guiding ground for forms of political resistance.

\subsection{From "Enemies of Urban Cleaning" to "Priority Agents" of the Selective Collection Programme (1993 - 1998)}

In 1992's municipal elections, the coalition Frente BH Popular, leaded by the Workers Party (PT) with Patrus Ananias, won. A new work regarding solid waste management in Belo Horizonte was born in this mandate. The position of SLU director was assigned to a sanitary engineer who, such as Ananias, already supported Asmare's work.

During this period, a group of changes in the solid waste policies occurred, among them the creation of a programme for selective collection through the joint work of SLU, Street Pastoral and Asmare. Based on this joint work, it was decided that selective collection would take place through the voluntary delivery of recyclable waste to assigned places (LEVs, in Portuguese), in which the population could place recyclable materials already separated at home. And scavengers would collect them with their human-traction carriages. The agreement was signed between the municipal government, Asmare and the Street Pastoral and an addendum was added to extend the scope of the municipal government's action and to formally recognise Asmare as a prioritary partner in the selective collection programme, in Belo Horizonte. 
The public power's attributions were related to the creation of necessary conditions for the association's functioning such as providing the logistic and operational structure to support the work of scavengers, with the selection of sheds and implementation of the LEVs; advising the formation process through SLU and the Municipal Secretariat for Social Development (SMDS in Portuguese), and transferring monthly financial resources to keep the facilities as well as the provision of uniforms, individual security equipments and buss-passes to scavengers.

SLU has created the Department of Social Mobilisation (MAS, in Portuguese) to build the selective collection programme and to develop new actions in terms of urban cleaning such as environmental education and awareness of the population. One of the MAS team's first joint actions with the Street Pastoral was the registration of the existing scavengers in the city's main places of grouping, aiming to integrate them to Asmare. The team has identified 49 points where scavengers and recyclable waste were concentrated, which for different reasons was a cause of constant complaints coming from the population. The ex-coordinator of the selective collection programme reported that:

people wanted us to clean the city, the way we saw it, they wanted us to collect that bunch of solid waste, material and human ones, and take them, compact them and take them to the landfill. The impression, I say, it is the best, is the form how I translate our feelings. They said 'look, the city is filthy, because of those scavengers', I mean, they complained about us as much as about the waste, it was a huge problem, this one. (Ex-coordinator of selective collection programme - Free translation)

On this speech, as well as in others, it is possible to notice the lack of relations of respect and the perception of that context and of the situation of scavengers as "human waste" (Bauman, 2005), that is, considered as redundant dispensable individuals that share the semantic universe of "discarding" and "waste" and, literally surviving out of the waste, living in the waste and considered as waste, in a situation in which Bauman's (2005) metaphor kind of fits in a interesting way. Although scavengers are not, by any means, dispensable in the distinct productive chains of recycling (plastic, paper, etc), once they are the ground support for almost all chains (Bosi, 2008). This speech also shows the constant tension between disrespect and recognition.

During this period, Asmare went through a restruction process and grew. The number of members in 1993 was 31 , growing to 156 in 1994, 183 in 1995 and 210in 1997. Scavengers were able to access a few rights. In their narratives substantial improvements in their lives and daily work were highlighted. There was the construction of new forms of interaction among them and in the relation with other people, so that new practical self-relations were built, even if in a wider context the recognition was still denied.

A former social mobilisation anaylist reported that, during this period, the degree of interaction with the public power was so large that the Street Pastoral had the idea of creating a management college in Asmare where Pastoral agents, members of SLU and SMDS participated to contribute to the association's technical and operational management. This relation has been kept in the next Municipal Government of Belo Horizonte's mandate.

The dispute for the municipal government in 1996 was won by Célio de Castro, of the Brazilian Socialist Party (PSB), who was the deputy-mayor during the previous mandate. A former social mobilization analyst mentioned that, during Célio de Castro's mandate (1997-2000), the post of SLU director was given to another person because of political issues related to bargaining between coalition parties. But the mayor imposed the condition that the team should be kept despite the change in the direction. The team's maintenance, including political and technical position, has contributed to the continuity of the developed work.

It is important to highlight that the process of formulation and implementation of the policy in support of the work developed by the scavengers was joint, involving state bureaucrats and the civil society - Asmare and the Street Pastoral. It was a participatory process for the construction of public policy, in a social and political context that was open to such practices in the relation between the State and the society.

4.3 Political and Social Consequences: Dissemination of the Experience and the Construction of New Spaces for Political Articulation (1999-2004)

In 1999, the Street Pastoral and Asmare were requested to disseminate the experience of scavengers' organisation to other cities. A former Pastoral agent reported that this demand has initially appeared with the National Programme Waste and Citizenship.

The first dissemination actions took place in 1999 through a pilot consulting work in the scope of the Waste and Citizenship National Programme in the municipalities of Brumadinho and Ibirité, located in the Belo Horizonte's metropolitan region. The goal was to eradicate child work in these municipalities' dumpsites. In 2000, the 
consulting action had already been expanded to 14 cities in Minas Gerais and in the end of 2001 there were 33 cities.

In this period, Asmare gained national and international repercussion. The association and the selective collection programme received several awards. The awards became a way to reinforce the importance of the work that was being developed and at the same time reinforce the meaning around scavengers' social values. This could be understood as a contribution to help scavengers from being devalued, a priori in their interactions.

At this time, the process of MNCR education was also started. The Pastoral coordinator says that through the National Forum of Studies on Homeless, in which it is a member, they have initially articulated groups in Minas Gerais, São Paulo, Porto Alegre and Rio de Janeiro and then expanded the action to other states. The coordinator said that MNCR's creation, in 2001, was the peak moment because they could "understand they are not alone, that this reality is not exclusive to Belo Horizonte, or Minas Gerais, but it is in Brazil and it can strengthen their struggle" (Pastoral coordinator - free translation) The education of the national movement appears to be a process in which scavengers realised that the disrespect they individually suffer reach many others in the whole country.

In the 2000 elections, Célio de Castro was reelected to the position of mayor, but for health reasons he left the post in 2001 and Fernando Pimentel (PT), his deputy-mayor, took over the city government. During his mandate, an administrative reform was conducted and SLU was no longer an autarchy and became the Municipal Secretariat for Urban Cleaning and regional sub-secretariats were created. The narrative of some SLU employees that worked during this period match the perception that the reform was a mistake, that it provoked the disrupting of the department and generated negative consequences in the conduction of the solid waste policy and in the selective collection programme.

\subsection{Inflections in the Policy to Support the Work of Scavengers (2005-2010)}

In the 2004 elections, Fernando Pimentel (PT) was reelected mayor of Belo Horizonte. In his new mandate, some changes were made in the structure of the selective collection programme and new conflicts in the relation with scavengers occurred.

One of the mentioned events was the interdiction of Asmare's shed in July 2006. A former Pastoral agent and some scavengers reported that municipal inspectors and the police arrived to close the place due to the lack of fire combat equipments, making use of physical violence. He argued that in fact the association did not have any fire equipment because they didn't have financial resources for that, and that the shed was built and delivered by the municipal government without such structure. He also said that afterwards, equipments were installed and they have officially reopened, but until today, the municipal government denies them the license to operate. Such situation shows a contradiction and a lack of dialogue considering that Asmare acts in the scope of an agreement with the Municipal Government and delivers the public service of collecting recyclable material integrating the selective collection programme.

The outsourcing of the selective collection services, put in operation in 2007, was another highlighted event. An Asmare scavenger, who is today a MNCR leader, mentioned they did several demonstrations and marches to protest against outsourcing. Many scavengers were afraid that collecting would become impossible. In almost all narratives the conflict was highlighted, but the meanings attributed to the event were different. On one hand, mostly in the narratives of some members of the public power, the outsourcing of the selective collection occurred due to SLU's operational incapability and the incapability of the scavengers' organisations to perform the door to door collection. On the other hand, in some narratives, the outsourcing is seen as a form of predominance of the "great capital" interests in an attempt to exclude the scavenger from the process and take away this group's living resources. These meanings are present in the narratives of the coordinator and of former Pastoral agents and of a scavenger who was MNCR's leader. A former Pastoral agent mentioned that the outsourcing of both selective and conventional collection services was legitimised based on a strategy previously conducted, that is, the administrative reform which provoked the SLU disassemble and reduced its capacity for delivering services. He highlighted that the outsourcing of the selective and conventional collection services in Belo Horizonte took place because of the predominance of economic interests in a market that started to call the attention of other sectors with larger economic and political power since waste has become business.

With the beginning of the outsourcing in 2007, the hired company started to perform the door to door collection in 21 neighbourhoods. Yet SLU, with its own resources, performed the collection in nine neighbourhoods. This way, only 30 out of 148 neighbourhoods were included. One of the selective collection programme's coordinator mentioned that "we are playing selective collection", because the amount of neighbourhoods included and the percentage of the material which is actually recycled in comparison to the total amount of solid waste generated in 
the municipality is very small. In 2009 , only $0.8 \%$ of the total amount of solid waste generated in the city was recycled by the selective collection programme (Slu, 2009).

Another mentioned event was the creation of a decree that regulated the scavengers' activity in the municipality. A former Pastoral agent said that the elaboration of such decree did not involve the participation of scavengers or of any civil society organization related to the issue. Among the rules, the decree established that street collection would only be allowed between 19:30 and 7:00, arguing that the scavengers' presence in the streets disturbed the traffic. He mentioned that this action was a municipal strategy associated to the outsourcing process once that with the planned schedule, by the time scavengers reached the house, the material would have already been collected by the municipality, forcing them to eventually give up for not finding any material to be collected. He also said that demonstrations against the decree were made and they sought to get support from the Minas Gerais' Public Ministry (MP-MG, in Portuguese) that has required the decree's rewriting by a group work with the participation of scavengers, support organisations and the MP-MG.

The work of scavengers and the repression against their work restarted. Although such actions were not as extreme as before, like in the "cleaning operation" case, they are not less damaging to their physical and social integrity and to their dignity. Disrespect continues with the deprivation of rights, degradation and offence and even physical aggression, such as narrated in the event for the closure of Asmare's shed and headquarter.

The current situation of the policy in support of the scavengers' work in Belo Horizonte:

In the 2008 elections, Márcio Lacerda (PSB) became mayor. In the beginning of his mandate, he expressed his plan to maintain the selective collection programme, but his focus would be the conventional collection, as reported by scavengers, a former Pastoral agent and current SLU employees.

Nowadays, the relation between Asmare and the Municipal Government is restricted to the agreement established since 1993, on the scope of the SMAAS with the transference of financial resources for the payment of administrative employees, provision of uniforms and buss-passes for the scavengers. Asmare is composed by 250 members. In general, the work conditions are still precarious. After the advancement obtained in the 90s, there was no significant change. Scavengers are still pulling their chariots, the selection is made in sheds without the suitable structure, the income is still low and susceptible to flows in the recyclables market and the sale of materials is still made by middle men. Scavengers' current claims are mainly related to retirement and payment for the services rendered to the local government, such as regulated by the Law 11.445/07.

It is important to point that the inflection in the policy to support the work of scavengers in Belo Horizonte has occurred in parallel with federal advancements. In 2002, the recognition of the "collector of recyclable material" job by the Brazilian Code of Jobs (CBO, in Portuguese) played a symbolic role and gave public visibility to the scavenger. In 2003, a presidential decree created the Inter-Ministerial Committee for the Social Inclusion of Scavengers. In 2006, the decree 5.940 was published, previewing that all public departments should participate in the selective collection and donate the material for scavengers' cooperatives. Through the Law 11.445/07, which alters the National Policy for Sanitation, public governments are allowed to hire, with no bidding, organisations of scavengers to render services of selective collection. In the scope of the Ministry for Social Development and Fight against Hunger the beginning of actions related to social and productive inclusion to support scavengers began. Another federal advancement was the approval, in 2010, of the National Policy for Solid Waste (Law n 12.305), recognizing the inclusion of scavengers in municipal selective collection programmes.

\section{Final Considerations}

The relation of Asmare's scavengers with the public power has involved several conflicts, in a process that was full of ups and downs between 1987 and 2010. In this period, changes were made in the meanings and notions attributed to scavengers and their work, generating impacts in the scavengers' struggle and in the State's response approaching the social problem.

As seen, the construction process of policies to support the scavengers' work was possible through their own organization within an association like the Street Pastoral. In the 90s, the policy was built along the scavengers, so that this participation in the construction and implementation of such policy was one of the elements that allowed successful results during the initial years. The policy tried to incorporate and promote the social recognition of scavengers in a dynamics marked by the constant tension between disrespect and recognition. Some advancements were made, although scavengers are still in a situation of denied recognition, suffering different forms of disrespect. We have noticed that when, in the middle of the 2000s, inflection took place in the policy, the participation of scavengers was no longer in place in the implementation of such policies with the same intensity as in the previous years, as well as priorities were redefined with the changes in the government. 
These changes show us how the policy in support of the scavenger's work in Belo Horizonte is still fragile and depends, most of the time, on political will; which can evidence the influence people can have on such process and the low institutionalisation of effective policies. It is important to mention that the institutionalisation of policies does not guarantee, alone, the juridical recognition or any other form of recognition, but it is an important element to allow, mainly the access to rights, considering the increased Brazilian social inequality.

It is worth noting that as waste became valuable and a new business field, it attracted the interest of other segments of society with greater economic and political power. This was evident in the process of outsourcing selective collection in Belo Horizonte, in which the relationship between scavengers and local authorities became more conflicted.

It is important to mention that the scavengers are still suffering from different forms of disrespect, but it seems like some meanings help to avoid the a priori devaluation, such as the attention that was brought to the environmental importance of their work. Besides, engaging the association enabled scavengers to realise their social value and which gave them back their lost self-confidence, self-esteem and self-respect. Although Honneth (2003) argues that only the denial of juridical recognition and social esteem could be able to start social conflict, in the analysed case it seems like it is not possible to separate the sphere of emotional dedication from the corresponding disrespect (physical abuse) of the other spheres of recognition. The struggle of scavengers has involved the questioning of the three forms of disrespect: the physical aggression that occurred in "cleaning operations"; the deprivation of basic rights and the social exclusion, such as being denied their rights to work, food and housing; and the degradation and insult that occurred through prejudiced and humiliation.

As a result of theoretical-methodological choices, this research presents a few limitations that open possibilities for new studies. In theoretical terms, it would be interesting to deepen the discussion on recognition theory and potentially articulate it with theories of social movements and organizational studies. In methodological terms, other paths may be taken, but despite their limitations, the methods we adopted allowed us to comprehend the ebb and flow of the investigated experience in its historic building process, as well as the constant tensions between disrespect and recognition. Studying the struggle of Asmare's scavengers revealed different possibilities for future studies, as it interacts with interesting issues that could be explored. One possibility would be to research the process of forming the National Scavenger Movement and the formulation of federal public policies. Comparative studies on the relationship between scavengers' organizations with local governments in different Brazilian cities is another possibility.

By examining Asmare's experience, we can observe the importance of scavenger participation in building and implementing public policies aimed at them. The policy's successful results in the 1990s arose, among other factors, from a shared construction process. This aspect may be an important element for implementation of the National Policy for Solid Waste, which establishes the integration of scavengers in selective collection programs.

This research shows the importance of broadening our perception of how civil society actors are able to influence the processes of formulation and implementation of public policies, as well as of how social conflict and dynamics of struggle are present in the relations between State and civil society in the Brazilian context.

\section{References}

Alves, M. A., \& Blikstein, I. (2006). Análise da narrativa. In: C. K. Godoi, R. Bandeira-De-Mello, \& A. B. Silva (Eds.), Pesquisa qualitativa em estudos organizacionais: paradigmas, estratégias e métodos (pp. 403-428). São Paulo: Saraiva.

Bauman, Z. (2005). Vidas desperdiçadas. Rio de Janeiro: Jorge Zahar.

Belo, H. (1990). Lei Orgânica do Município de Belo Horizonte. Belo Horizonte.

Bosi, A. P. (2008). A organização capitalista do trabalho "informal" - o caso dos catadores de recicláveis. RBCS, 23(67).

Czarniawska, B. (2000). The uses of narrative in Organization Research. Gothenburg: Gothenburg Research Institute - School of Economics and Commercial Law, Göteborg University.

Czarniawska, B. (2004). Narratives in Social Science Research. London: SAGE Publications.

Fraser, N. (2007). Reconhecimento sem Ética? Revista Lua Nova, 70, 101-138. http://dx.doi.org/10.1590/S0102-64452007000100006

Fraser, N., \& Honneth, A. (2003). Redistribution or recognition? A political-philosophical Exchange. London: Verso. 
Godoy, A. S. (2006). Estudo de Caso Qualitativo. In: C. K. Godoi, R. Bandeira-De-Mello, \& A. B. Silva (Eds.), Pesquisa qualitativa em estudos organizacionais: paradigmas, estratégias e métodos (pp. 115-146). São Paulo: Saraiva.

Honneth, A. (1996). Reconocimiento y obligaciones morales. RIFP, 8, 5-17.

Honneth, A. (2003). Luta por reconhecimento: A gramática moral dos conflitos sociais (34th ed.). São Paulo.

Honneth, A. (2007). Reconhecimento ou distribuição? A mudança de perspectivas na ordem moral da sociedade. In J. Souza, \& P. Matos (Orgs.), Teoria crítica no século, XXI, 79-93. São Paulo.

Honneth, A. (2008a). Reification: a new look at an old idea. New York: Oxford University Press.

Honneth, A. (2008b). Observações sobre a reificação. Civitas, 8(1), 68-79.

Honneth, A. (2008c). Trabalho e reconhecimento - Tentativa de uma redefinição. Civitas, 8(1), 46-67.

Layargues, P. (2002). O cinismo da reciclagem: o significado ideológico da reciclagem da lata de alumínio e suas implicações para a educação ambiental. In F. Loureiro, P. Layargues, \& R. Castro (Orgs.) Educação ambiental: repensando o espaço da cidadania (pp. 179-220). São Paulo: Cortez.

Marshall, T. H. (1967). Cidadania, classe social e status. Zarhar Editores, Rio de Janeiro.

Mattos, P. (2006). A sociologia política do reconhecimento - As contribuições de Charles Taylor, Axel Honneth e Nancy Fraser. São Paulo: Annablume.

Mendonça, R. F. (2009). Dimensão intersubjetiva da autorrealização: Em defesa da teoria do reconhecimento. RBCS, 24(70), 143-154. http://dx.doi.org/10.1590/S0102-69092009000200009

Pettigrew, A. M. (1990). Longitudinal field research on change: Theory and practice. Organization Science, 1, 267-292. http://dx.doi.org/10.1287/orsc.1.3.267

Pinsky, J, \& Pinsky, C. B. (2003). A história da Cidadania. São Paulo: Contexto.

Portilho, F. (2005). Consumo sustentável: Limites e possibilidades de ambientalização e politização das práticas de consumo. Cadernos Ebape.br, 3(3), 1-12. http://dx.doi.org/10.1590/S1679-39512005000300005

Prefeitura M. B. H. (2008). Decree n 13.378, November 12, 2008. Belo Horizonte.

Sennett, R. (2004). Respeito: A formação do caráter em um mundo desigual. Tradução de Ryta Vinagre. Rio de Janeiro: Record.

Souza, J. (2009). A Ralé Brasileira-quem é e como vive. Belo Horizonte: Editora UFMG.

Spink, P. K. (2003). Pesquisa de campo em psicologia social: Uma perspectiva pós-construcionista. Psicologia e Sociedade, 15 (2), 18-422. http://dx.doi.org/10.1590/S0102-71822003000200003

Spink, P. K. (2008). O pesquisador conversador no cotidiano. Psicologia e Sociedade. Edição Especial, 20 , 70-77.

Superintendência L. U. (2009). Relatório Anual de Atividades da Limpeza Urbana - 2009. Belo Horizonte, $\mathrm{CEMP/SLU/PBH.}$

Yin, R. K. (2001). Estudo de caso: Planejamento e métodos. Porto Alegre: Bookman.

Notes

Note 1. Open sky landfill for dumping solid waste.

Note 2. Axel Honneth seeks to present a solution to the problems detected on the predecessors of the Critical Theory, who, according to him, have a "sociological deficit". To Honneth, even Habermas, who has put great sociological weight in his work could not correct this deficit existing in the Critical Theory. 